\title{
Evaluation of liquid or foam sclerotherapy in small varicose veins (ceap c1) with venous clinical severity score
}

\begin{abstract}
SUMMARY
OBJECTIVE: We aimed to evaluate the efficacy of liquid or foam sclerotherapy of varicose veins using venous clinical severity scores and possible complications.

METHODS: A total of 318 patients (268 females, 50 males) who were treated with liquid or foam sclerotherapy between January 2012 and December 2012 were included in this study.

RESULTS: Skin necrosis was observed in only 6 patients (1. 8\%), thrombophlebitis in 10 patients (3. 1\%), and hyperpigmentation in 18 patients (5. 6\%) in this study group. The mean venous clinical severity score was calculated as: pain score, $1.23 \pm 0.88$; varicose vein score, $1.85 \pm 0$. 8; edema score, $0.64 \pm 0.77$ ). Pain and edema decreased at the control examination, 1 month after completion of sclerotherapy sessions. Varicose veins completely disappeared after sclerotherapy. While the decrease in edema in the foam sclerotherapy group was significantly less $(P<0.001)$, the decline in pain showed an increasing trend $(P=0.069)$. While skin necrosis did not develop after foam sclerotherapy, rates of pigmentation and local thrombophlebitis were similar $(P>0.05)$.

CONCLUSION: In conclusion, we observed that both sclerotherapy methods are effective with a low rate of complications, alleviating the complaints of patients with small varicose veins, and providing considerable improvement in venous clinical severity scores.

KEYWORDS: Venous Clinical Severity Score, Reticular Veins, Sclerotherapy
\end{abstract}

\section{INTRODUCTION}

Chronic venous insufficiency (CVI) causes considerable loss of work power, has adverse effects on the quality of life of patients and high prevalence, with $25-33 \%$ in women and $10-20 \%$ in men ${ }^{1}$. Furthermore, venous insufficiency associated with varicose veins cause frequent complications and cosmetic problems ${ }^{2}$. On the other hand, clinical, etiologic, anatomic, and pathophysiologic (CEAP) classification is a method of stratifying patients who have varicose veins and venous disease according to the severity of their presentation. In addition to the CEAP classification, venous clinical severity scoring system (VCSS) is also used in patients with chronic venous insufficiency ${ }^{3}$. This scoring system has been proposed by the American Venous Forum Ad Hoc Committee.

Telangiectasias associated with venous insuffi-

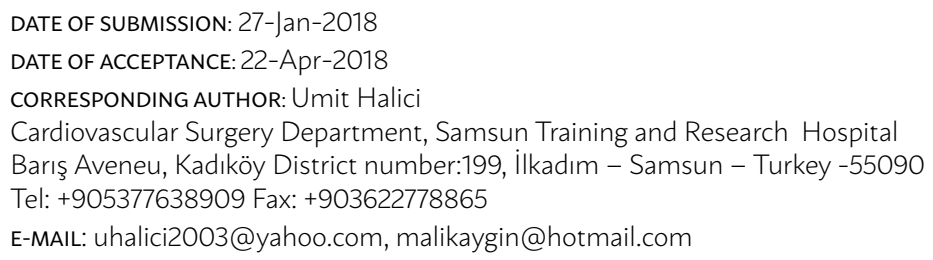


ciency generally have diameters between $0,1-1 \mathrm{~mm}$ and sclerotherapy is especially effective for this type of varicosity ${ }^{4}$. Complete chemical endothelial damage with inflammation develops with sclerotherapy 5. Sclerotherapy cause transmural injury in vessel wall after endothelial damage ${ }^{6}$. Sclerotherapy is one of the most up-to-date approaches in the treatment of telangiectasias and varicose veins of the reticular type (1-3 mm diameter).

This study aimed to evaluate the complications and efficacy of foam and liquid sclerotherapy for telangiectasias and reticular type varicose veins of small diameter (CEAP 1 class), using VCSS and the medical literature retrospectively.

\section{METHODS}

Between January 2012 and December 2012, files of a total of 980 patients who were treated with sclerotherapy due to reticular type varicose veins or telangiectasias were screened. Before sclerotherapy, the patients were examined with venous color flow Doppler ultrasonography (CDUSG). From these patients, 318 were included in this retrospective study (268 females, 50 males; mean age $36.7 \pm 11.1$ years), whose preoperative and postoperative medical records from the outpatient clinics could be found. The medical records of the patients were examined and the patients were divided into groups treated with liquid sclerosing (Group 1; 74 females, 25 males, mean age: 39.3 \pm 11 years, range 18-64) or sclerosing foam agent (Group 2; 194 females, 25 males, mean age; 35.6 $\pm 10,5$ years, range 18-64). Foam sclerotherapy was conducted according to the Tessari method. In the present study, 0.5\%-1\% polidocanol (lauromacrogol 400) (Aethoxysklerol ${ }^{\circledR}$, Keussler Pharma, Wiesbaden, Germany) solution at a maximal dose of $0.5 \mathrm{ml}$ for each vein was used, and the $2 \mathrm{mg} / \mathrm{kg}$ total dose was not exceeded. A dose of $0.5 \%$ polidocanol was administered to telangiectasias of $<1 \mathrm{~mm}$ diameter in both groups, while $1 \%$ polidocanol was administered to varicose veins of the reticular type of 1-3 mm diameter.

Patients with prominent venous insufficiency in CDUSG and those that received additional treatments, such as stripping, endovenous laser ablation, perforator vein ligation were excluded. There were varicose veins in both lower extremities in 44 patients (24.5\%). The demographic characteristics of the patients are summarized in Table 1 .

Sclerotherapy was administered to all patients with telangiectasias of 0.1-1 $\mathrm{mm}$ diameter or reticular veins of 1-3 mm diameter. The decision for sclerotherapy was reached after exclusion of insufficiency of the saphenous vein, deep veins and perforator veins utilizing careful physical examination and CDUSG. 30 G needles were used for sclerotherapy. Foam sclerotherapy was done while the leg was elevated at $45^{\circ}$, and the leg was rested at $45^{\circ}$ for 10 minutes after the intervention. After compresses were placed over the varicose veins, the leg was wrapped with elastic straps, and compression therapy was continued for 2 days. Liquid sclerotherapy was done while the patient was lying down, and all patients were treated with compression therapy for 2 days with elastic straps. All patients returned to their normal daily activities after observation of at least half an hour at the outpatient clinics.

VCSS is based on scoring between 0 and 3 for clinical complaints and findings such as pain, varicose veins, edema, skin pigmentation, inflammation, induration, number of active ulcers, the diameter of active ulcers and past conservative treatments (compression socks and elevation) ${ }^{3}$. VCSS values before intervention and one month later were used in the evaluation of liquid and foam sclerotherapy in this study.

\section{Statistical analysis}

Changes in VCSS scores according to sclerotherapy method were evaluated with repeated common variable analysis. The pre-procedural characteristics of patients in the liquid and foam sclerotherapy groups were assessed by chi-square $\left(\chi^{2}\right)$ test (Table 1.) $(p=0.029)$. The differences in the number of post-procedural complications of the groups were evaluated with the Mann-Whitney U test. The statistical analysis was done with SPSS 12.0 (SPSS Inc., Chicago, USA) software. $\mathrm{P}<0.05$ was considered as statistically significant.

TABLE 1. PRE-PROCEDURAL PATIENT CHARACTERISTICS

\begin{tabular}{l|l|l|l} 
& $\begin{array}{l}\text { Liquid Sclerosing } \\
\text { Agent Treatment } \\
\text { Group }\end{array}$ & $\begin{array}{l}\text { Foam Sclerosing } \\
\text { Agent Treatment } \\
\text { Group }\end{array}$ & P values \\
\hline Edema & $1(0-3)$ & $0.48(0-3)$ & 0.001 \\
\hline Pain & $1.31(0-3)$ & $1.19(0-3)$ & 0.610 \\
\hline Varicose varices & $2.11(1-3)$ & $1.75(1-3)$ & 1.120 \\
\hline Patient age & $39.3 \pm 11$ & $35.6 \pm 10,5$ & 0.006 \\
\hline Gender F/M & $74 / 25$ & $194 / 25$ & 0.002 \\
\hline
\end{tabular}

$P<0.05$ was considered as significant with $\chi^{2}$ test 


\section{RESULTS}

The mean VCSS values in the pre-procedural evaluation of the patients were $1.23 \pm 0.88$ for pain, 1.85 \pm 0.8 for varicose veins, and $0.64 \pm 0.77$ for edema. The edema score, mean patient age, and proportion of male patients were higher in patients treated with liquid sclerotherapy (Table 1.). No patient in any group had pigmentation, inflammation, induration, and ulcer. Pain showed a decrease of $0.3 \pm 0.45$ points and edema $0.1 \pm 0.12$ points at the 1st-month control examination after completion of sclerotherapy sessions. Varicose veins disappeared completely (Table 2.).

Skin necrosis was observed in 6 patients (6\%) who were treated with liquid sclerotherapy, thrombophlebitis in $4(4 \%)$ and increase in pigmentation in 7 patients (7\%) in the present study. Skin necrosis was not seen in patients treated with foam sclerotherapy, but pigmentation developed in 11 patients (5\%), and thrombophlebitis developed in 6 patients $(2.7 \%)$. Standard treatment for thrombophlebitis was administered to patients with thrombophlebitis. Local antibiotherapy and local epithelialization treatment were applied to patients with skin necrosis. Skin necrosis and thrombophlebitis were found to be improved at the control examination at the 1st month
(Table 3.). Deep vein thrombosis and anaphylaxis did not occur in any patient. Local chondroitin polysulfate treatment was administered to the 15 patients (1.53\%) with hyperpigmentation. Hyperpigmentation was found to be decreased at the control examination after 1 month of treatment.

Pain, temporary edema and swelling were observed in the patients for 2-3 days after sclerotherapy. Venotonic medications used in venous insufficiency and elastic bandage were administered to the patients for temporary edema, and swelling and all patients who underwent sclerotherapy were given 2x25 mg indomethacin for 5 days as analgesic/anti-inflammatory drug. Patients with very severe complaints were treated with bed rest and elevation. A mean of 1.95 sessions (range 1-8) of sclerotherapy were administered for the closure of varicose dilations.

\section{DISCUSSION}

Sclerotherapy was administered to patients without deep vein insufficiency having complaints of edema and pain in their legs, and patients with telangiectasic varicose veins who had cosmetic complaints about the appearance of their legs, by using foam and

TABLE 2. CHANGE IN VCSS ACCORDING TO SCLEROTHERAPY METHOD

\begin{tabular}{|c|c|c|c|c|c|c|}
\hline \multirow[b]{2}{*}{$\begin{array}{l}\text { Symp- } \\
\text { toms }\end{array}$} & \multirow[b]{2}{*}{ Classification } & \multicolumn{2}{|c|}{ Liquid sclerosant treatment group } & \multicolumn{2}{|c|}{ Foam sclerosant treatment group } & \multirow[t]{2}{*}{$P$ values } \\
\hline & & Pre-treatment & Post-treatment & Pre-treatment & Post-treatment & \\
\hline \multirow[t]{4}{*}{ Edema } & None & 32 & 86 & 137 & 192 & \multirow{4}{*}{0.001} \\
\hline & Mild & 37 & 13 & 61 & 26 & \\
\hline & Moderate & 28 & 0 & 19 & 1 & \\
\hline & Severe & 2 & 0 & 2 & 0 & \\
\hline \multirow[t]{4}{*}{ Pain } & None & 14 & 84 & 53 & 157 & \multirow[t]{4}{*}{0.069} \\
\hline & Mild & 46 & 14 & 93 & 61 & \\
\hline & Moderate & 33 & 0 & 51 & 1 & \\
\hline & Severe & 6 & 0 & 22 & 0 & \\
\hline \multirow{3}{*}{$\begin{array}{l}\text { Varicose } \\
\text { veins }\end{array}$} & Mild & 24 & 0 & 112 & 0 & \multirow[t]{3}{*}{1} \\
\hline & Moderate & 45 & 0 & 53 & 0 & \\
\hline & Severe & 35 & 0 & 54 & 0 & \\
\hline
\end{tabular}

Changes in VCSS scores were evaluated with repeated common variable analysis. P $<0.05$ was considered as significant. VCSS; Venous clinical severity score

TABLE 3. COMPLICATIONS OBSERVED AFTER LIQUID SCLEROTHERAPY AND FOAM SCLEROTHERAPY

\begin{tabular}{l|l|l|l} 
& $\begin{array}{l}\text { Liquid Sclerosant Treatment } \\
\text { Group }\end{array}$ & $\begin{array}{l}\text { Foam Sclerosant Treatment } \\
\text { Group }\end{array}$ & P values \\
\hline Thrombophlebitis (regional) & $4(4 \%)$ & $6(2.7 \%)$ & 0.538 \\
\hline Pigmentation & $7(7 \%)$ & $11(5 \%)$ & 0.464 \\
\hline Skin necrosis & $6(6 \%)$ & 0 & 0.001 \\
\hline
\end{tabular}

$\mathrm{P}<0.05$ was considered as significant with Mann-Whitney $U$ test. 
liquid sclerotherapy methods. A noticeable improvement was observed in both groups regarding edema and pain, as seen in Table 2. Varicose veins completely disappeared with the use of both methods. Significant decreases in VCSS scores were recorded in comparison with baseline values with both methods.

Jia et al. ${ }^{7}$ have reported that sclerotherapy may cause complications such as anaphylaxis, skin necrosis and ulceration, deterioration in vision, migraine, cough, minor vein thrombosis, hematoma, thrombophlebitis, skin pigmentation, and local neurological damage. Additionally, other potential complications of sclerotherapy include swelling (particularly with foot and ankle therapy), telangiectatic matting, nerve damage, painless infarction with arteriolar injection, phlebitis, and rarely deep vein thrombosis/ pulmonary embolism ${ }^{8}$. On the other hand, it was reported that the risk of deep venous occlusion after UGS in this series was lower when using highly diluted or undiluted sclerosant when treating veins less than $5 \mathrm{~mm}$ in diameter, and when restricting the volume of foam injected to less than $10 \mathrm{ml}^{9}$. Deep vein thrombosis and pulmonary embolism were not observed in this study.

Herein, the most frequently encountered complications were pigmentation, local thrombophlebitis, and skin necrosis. No allergic reactions were detected in any patient. The pigmentation observed in patients decreased with time, although the duration of compression was short (2 days). Also, a similar rate of complications was seen in much of in the literature.

Özcan et al. ${ }^{4}$ reported that skin necrosis was caused by a high concentration of sclerosing agent or the agent being injected out of the vessel. In the present study, edema decreased more with liquid sclerotherapy, and skin necrosis did not occur in the foam sclerotherapy group.

As it is well-known, telangiectasis and reticular veins develop from venous hypertension. The most crucial factor in the etiology of varicose veins is a familial predisposition, followed by other factors such as being overweight, occupations requiring continuously standing up, pregnancy, lower extremity traumas, and masses compressing on the veins ${ }^{10}$.

Absolute contraindications for sclerotherapy include hypersensitivity against the sclerosing agent, systemic severe illness, local infection in the area where sclerotherapy is to be applied or systemic severe infections, acute superficial or deep vein thrombosis, advanced peripheral arterial disease (Fontaine stage 3 or 4), immobility, bed-ridden conditions,
Hyperthyroidism (with iodine-containing sclerosants), confinement to bed and pregnancy ${ }^{11}$. Relative contraindications include advanced leg edema, the presence of late complications of diabetes (e.g., polyneuropathy, bronchial asthma), Fontaine stage 2 peripheral arterial disease, known hypercoagulability, poor general condition, bronchial asthma, pronounced allergic diathesis, thrombophilia (with or without a history of deep vein thrombosis) ${ }^{11}$. In the present study, patients were questioned on the presence of absolute or relative contraindications, and sclerotherapy was conducted on those without contraindications.

Sclerosants can be divided into three broad categories-osmotic agents, detergents, and irritant/ corrosives ${ }^{12}$. As well, common detergent sclerosants include polidocanol, sodium tetradecyl sulfate (STS), sodium morrhuate, and ethanolamine oleate. ${ }^{12}$. Polidocanol works similarly to STS as a detergent sclerosant and is used commonly in Europe ${ }^{13}$. On the other hand, Polidocanol usage is prevalent in Turkey. The total maximal single dose of Polidocanol for telangiectasia and reticular veins is $2 \mathrm{mg} / \mathrm{kg}$; the dose of STS is $10 \mathrm{ml}$ of $3 \%$ solution ${ }^{4}$. The amount of $0.5 \%-1 \%$ Polidocanol injection for telangiectasias and reticular veins is about 0.1-0.5 $\mathrm{ml}^{4}$. Özcan and Şenarslan ${ }^{4}$ reported in their study that sclerotherapy was found inexpensive, with low complication rate, does not need hospitalization, relieves leg pain and discomfort. Polidocanol dosages used in this study are inconsistent with that study, and similar results were also found.

Rabe et al. ${ }^{14}$ have suggested a preference of liquid sclerotherapy for $\mathrm{C} 1$ class reticular type varicose veins and telangiectasias according to CEAP classification, and foam sclerotherapy for C1 class varicose veins in 2013 European sclerotherapy guidelines. In the present study, liquid sclerotherapy was administered for telangiectasias, and foam sclerotherapy was preferred for reticular type varicose veins. As it is known, sclerotherapy is the standard treatment used for telangiectasic and reticular veins. Its chance of success is high if it is appropriately administered. The success of sclerotherapy depends on the administration technique, the sclerosing agent and its concentration, and the diameter of the vessel to be treated. Sclerotherapy administration became more natural as the operator administering sclerotherapy became more experienced in varicose veins of small diameter. Patients involved in this study did not require hospitalization. Also, sclerotherapy treatment 
did impair the patient's ability to work. The . Ccost of this treatment technique compared to other treatment modalities for chronic venous insufficiency is lower than others.

The most important limitation of this study is the absence of optimal randomization. The cause of this is the requirement for a change of indication according to the diameters of varicose veins, which in turn led to patients with different characteristics in two groups.

\section{CONCLUSION}

In conclusion, it was observed that both sclerotherapy treatment methods are effective with a low rate of complications, alleviating the complaints of patients with small varicose veins (leg pain, irritability, decreasing analgesic requirement, cramps, and leg edema), and providing considerable improvement in VCSS scores.

\section{Conflict of interest}

The authors declare the absence of any conflicts of interest concerning any phases of preparing and publishing this manuscript.

\section{Finance}

We declare the absence of any financial support in any phase of the investigation and writing of this manuscript.

\section{RESUMO}

OBJETIVO: Nosso objetivo foi avaliar a eficácia de líquido ou espuma na escleroterapia de varizes por meio de escores de gravidade clínica venosa e possíveis complicações.

MÉTODOS: Um total de 318 pacientes (268 do sexo feminino, 50 do sexo masculino) tratados com escleroterapia com espuma ou líquido entre janeiro de 2012 e dezembro de 2012 foi incluído neste estudo.

RESULTADOS: Necrose da pele foi observada em apenas seis pacientes (1,8\%), tromboflebite em dez pacientes (3,1\%) e hiperpigmentação em 18 pacientes (5,6\%) neste grupo de estudo. A média do escore de gravidade clínica venosa foi calculado como: dor pontuação

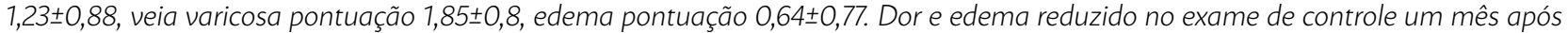
a conclusão das sessões de escleroterapia. Varizes desapareceram completamente após a escleroterapia. Enquanto a diminuição do edema no grupo de escleroterapia com espuma foi significativamente menor $(P<0,001)$, o decréscimo do nível de dor mostrou uma tendência a ser maior ( $P=0,069)$. Ainda que necrose da pele não tenha se desenvolvido após escleroterapia com espuma, as taxas de pigmentação e tromboflebite local foram semelhantes $(P>0,05)$.

CONCLUSÃo: Observou-se que ambos os métodos de escleroterapia são eficazes, com baixa taxa de complicações, aliviando as queixas de pacientes com varizes pequenas, e proporcionando uma melhora considerável nos escores de gravidade clínica venosa.

PALAVRAS-CHAVE: Escore de gravidade clínica venosa. Varizes. Veias reticulares.

\section{REFERENCES}

1. Köksal C, Alsalehi S, Kocamaz Ö, Sunar H. Kronik venöz yetmezlik tedavisi. Koşuyolu Kalp Dergisi. 2010;13:28-33.

2. Iriz E, Ereren E, Oktar S, Oktar L, Halit V, illhan M. Perforan venöz yetmezlikte miniflebektomi ile ligasyon. Türk Göğüs Kalp Damar Cer Derg. 2009;17:101-5.

3. Kakkos SK, Rivera MA, Matsagas MI, Lazarides MK, Robless P, Belcaro G et al. Validation of the new venous severity scoring system in varicose vein surgery. J Vasc Surg. 2003;38(2):224-8.

4. Özcan S, Şenarslan DA. Telenjiektazi ve retiküler venlerin tedavisinde skleroterapi. Bozok Tıp Dergisi. 2012;1:11-6.

5. Redondo P, Cabrera J. Microfoam sclerotherapy. Semin Cutan Med Surg. 2005;24(4):175-83.

6. Akbulut B, Tok M, Ucan Hi, Dündar B. Sık görülen venöz sistem hastalıkları görülme sıklığı, risk faktörleri ve tedavisi. Anatolian J Clin Invest. 2009;3:113-9.

7. lia X, Mowatt G, Burr JM, Cassar K, Cook J, Fraser C. Systematic review of foam sclerotherapy for varicose veins. Br J Surg. 2007;94(8):925-36.
8. Dietzek CL. Sclerotherapy: introduction to solutions and techniques. Perspect Vasc Surg Endovasc Ther. 2007;19(3):317-24.

9. Myers KA, Jolley D. Factors affecting the risk of deep venous occlusion after ultrasound-guided sclerotherapy for varicose veins. Eur J Vasc Endovasc Surg. 2008;36(5):602-5.

10. Soysal Ö, Gülcüler M, Cihan HB, Ege E, Gülcan Ö, Özdemir H, et al. Alt ekstremite varislerinin Polidokanol ile skleroterpisi. Turgut Özal Tıp Merkezi Dergisi. 1996;3:12-5.

11. Reich-Schupke $S$, Stücker M. Training in pictures: foam sclerotherapy. Phlebologie 2013;1:31-6.

12. Worthington-Kirsch RL. Injection sclerotherapy. Semin Intervent Radiol. 2005;22(3):209-17.

13. Mowatt-Larssen E. Management of secondary varicosities. Semin Vasc Surg. 2010;23(2):107-12.

14. Rabe E, Breu FX, Cavezzi A, Coleridge Smith P, Frullini A, Gillet JL, et al.; Guideline Group. European guidelines for sclerotherapy in chronic venous disorders. Phlebology. 2013;29(6):338-54. 